\title{
Pleomorphic adenoma of parapharyngeal space: a rare case report
}

\author{
Vijay Peruvaje, Yogesh Bandiahanapalya Narasappa*
}

Department of ENT, Mandya Institute of Medical Sciences, Mandya, Karnataka, India

Received: 20 February 2020

Accepted: 12 May 2020

\section{*Correspondence:}

Dr. Yogesh Bandiahanapalya Narasappa,

E-mail: yogibplkmc@gmail.com

Copyright: (C) the author(s), publisher and licensee Medip Academy. This is an open-access article distributed under the terms of the Creative Commons Attribution Non-Commercial License, which permits unrestricted non-commercial use, distribution, and reproduction in any medium, provided the original work is properly cited.

\begin{abstract}
Parapharyngeal space is one of the potential facial planes for neoplasms representing less than $1 \%$ of all head and neck tumours, often pose therapeutic and diagnostic problems due to variable nonspecific symptoms and the complex anatomy of the space and tend to delay the diagnosis resulting in poor prognosis. We here with report a 21 years old female patient, who presented with change in voice and swelling in right submandibular area. On examination of oral cavity, a smooth firm bulging mass was seen in the right tonsillar and para-tonsillar region with medialisation of right tonsil. Contrast enhanced computed tomography showed minimally enhancing encapsulated soft tissue density mass in right parapharyngeal space. Patient underwent excision through transcervical approach. Histopathology of the specimen showed pleomorphic adenoma. No evidence of recurrence till date.
\end{abstract}

Keywords: Pleomorphic tumour, Para-tonsillar, Medialisation

\section{INTRODUCTION}

Parapharyngeal space is one of the potential facial planes of head and neck that may become involved by various pathological processes. ${ }^{1}$ Pleomorphic adenomas of salivary glands may occur at any age, most common being in the 4-6 decades. Superficial lobe of parotid most commonly involved but, more rarely, these tumours may involve the deep lobe of the parotid gland (10-12\%). ${ }^{2}$ Tumours involving minor salivary glands and parapharyngeal space will be having late, atypical presentation with unpredictable and poor prognosis. Early diagnosis and radical surgical management offer the hope for cure of the disease, decreasing morbidity associated with it.

\section{CASE REPORT}

This is a case report of a 21 years old female patient, who presented with change in voice since, 2 months. Oral cavity examination showed a smooth firm bulging mass was seen in the right tonsillar and para-tonsillar region with medialisation of right tonsil (Figure 1).

On neck examination there was non-tender, firm to hard, lobulated swelling in right submandibular region with poorly defined border. Schwannoma, pleomorphic adenoma of deep lobe of parotid, malignancy of minor salivary glands and carotid body tumour were considered among the differential diagnosis.

Contrast enhanced magnetic resonance and imaging of neck showed a well-defined rounded minimally enhancing encapsulated soft tissue density mass in right parapharyngeal space (Figure 2). Intra oral fine needle aspiration cytology showed features suggestive of pleomorphic adenoma.

Patient underwent excision under general anaesthesia by transcervical incision, with intra-operative findings showed firm to hard grey white mass arising from minor salivary gland with deep lobe of parotid gland appears to be normal. Complete haemostasis was achieved. 
Procedure was uneventful. Patient was discharged after 5 days of hospitalisation.

Histopathological examination showed gross- a single, irregular, grey white nodular mass measuring $6 \times 3 \times 3 \mathrm{~cm}$ size (Figure 3). Microscopically, a benign tumour comprising of mixed epithelial and mesenchymal elements in varied proportions including lipometaplasia, cartilage and keratin suggestive of pleomorphic adenoma (Figure 4).

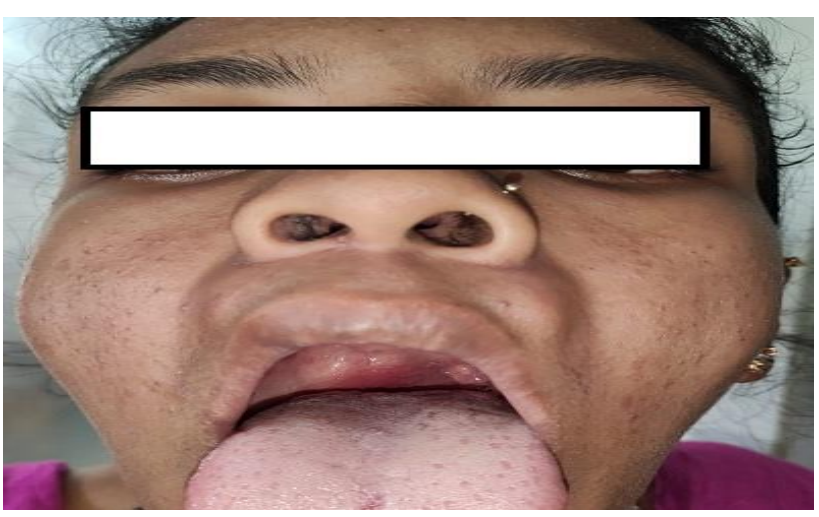

Figure 1: A smooth firm bulging mass in the right tonsillar and paratonsillar region with medialisation of right tonsil.

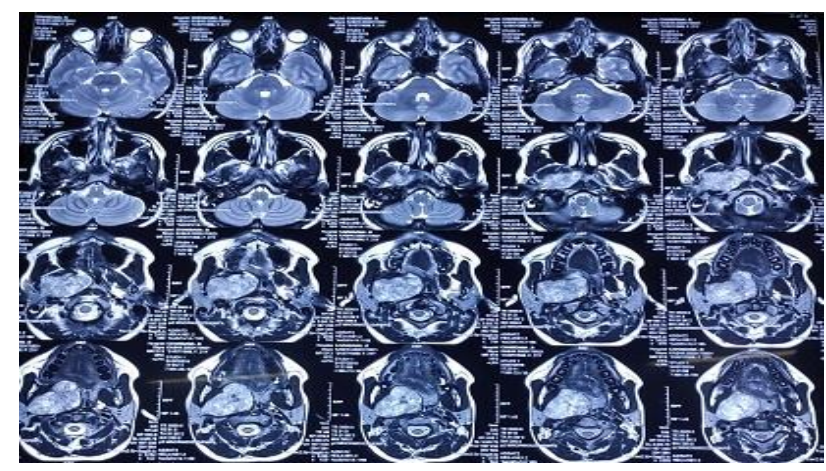

Figure 2: A well-defined rounded minimally enhancing encapsulated soft tissue density mass in right parapharyngeal space.

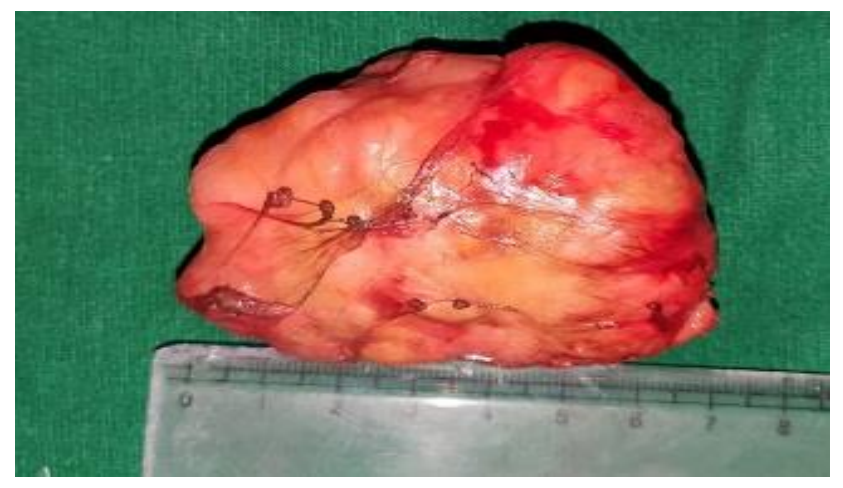

Figure 3: Gross a single, irregular, grey white nodular mass measuring $6 \times 3 \times 3 \mathrm{~cm}$ size.

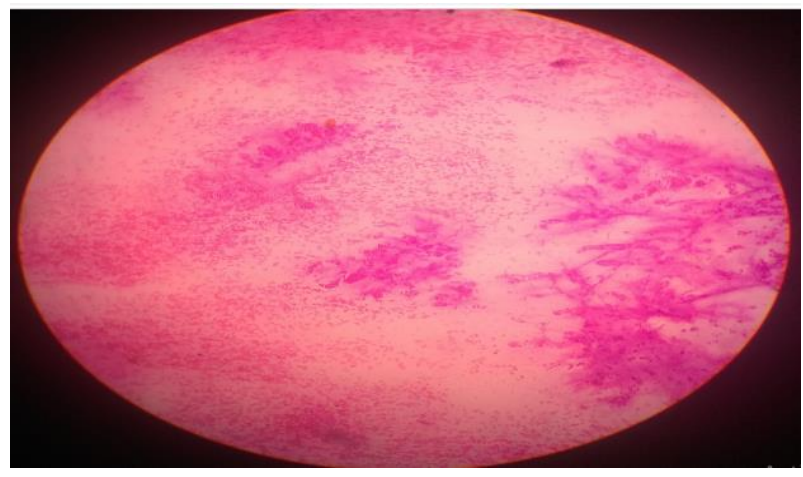

Figure 4: A benign tumour comprising of mixed epithelial and mesenchymal elements in varied proportions including lipometaplasia, cartilage and keratin suggestive of pleomorphic adenoma.

Patient tolerated the treatment well. Patient has been on regular follow-up and is asymptomatic with no recurrence till date.

\section{DISCUSSION}

Parapharyngeal space is an inverted triangular pyramid shape with concave faces, located posterior to infratemporal fossa, anteriorly nasopharynx, medially lateral pharyngeal wall, posteriorly vertebral column and laterally mandibular ramus. The base of the pyramid is situated on the skull base and the apex is directed towards hyoid bone. The space is further divided into pre-styloid and post-styloid compartments by styloid process and its attached muscles and fascia.

It is one of potential space of head and neck that may involve by various pathological processes: infectious, inflammatory, and neoplastic. Neoplastic tumours seen at the parapharyngeal space represent 0.5 to $1 \%$ of all head and neck tumours, where $70-80 \%$ appears to be benign and $20-30 \%$ appears to be malignant. Tumours from posterior compartment are of neurogenic origin while salivary gland tumours involve the anterior compartment. ${ }^{1}$

Deep lobe pleomorphic adenomas are discovered, during routine physical examination, as an asymptomatic mass, they remain silent for a long time.

Diagnostic imaging, such as CT or MRI, is mandatory in such cases in order not to miss any pathology present in the upper respiratory tract and to know the extent of the tumour. MRI is more informative in this type of case on account of its better definition of soft tissue, providing precise information concerning tumour margins as well as the relationship with the surrounding structures. ${ }^{2}$ Depending upon the location of the lesion, FNAC can be performed intra-orally or percutaneously. ${ }^{2}$

Various surgical approaches for removal of the tumor include trans parotid, transcervical, and trans mandibular 
routes. The surgical approach providing wide intra operative visibility for safe radical dissection, minimal function, and cosmetic after-effects is ideal for excision. ${ }^{9}$

Due to the complex anatomy, location and vital structures in the vicinity, resection of para-pharyngeal space tumors can prove challenging. Pleomorphic adenoma arising de novo in the parapharyngeal space is rare. An adequate clearance of the tumour with surrounding dispensable normal tissues is the key to successful treatment of such tumors. ${ }^{4}$

\section{CONCLUSION}

We conclude that, an exhaustive pre-operative diagnostic algorithm is required before approaching such a lesion to know the location and margins to guide the surgeon in planning for the right approach. The surgical approach should provide excellent visibility with wide surgical exposure to secure local neurovascular structures in our experience.

Funding: No funding sources Conflict of interest: None declared

Ethical approval: Not required

\section{REFERENCES}

1. Akın I, Karagoz T, Mutlu M, Şahan M, Onder E. Pleomorphic adenomas of the parapharyngeal space. Case Reports Otolaryngology. 2014;2014.

2. Datarkar AN, Deshpande A. Giant parapharyngeal space pleomorphic adenoma of the deep lobe of parotid presenting as obstructive sleep apnoea: a case report and review of the diagnostic and therapeutic approaches. J Maxillofacial Oral Surgery. 2015;14(3):532-7.
3. Bist SS, Luthra M, Agrawal V, Shirazi N. Giant parapharyngeal space pleomorphic adenoma causing acute airway obstruction. Oman Medical J. 2017;32(3):240.

4. Indulkar ST, Khare M, Khatib Y, Talpade YM. Primary pleomorphic adenoma of the parapharyngeal space. Med J Dr. DY Patil Vidyapeeth. 2018;11(5):420.

5. Guruprasad Y, Chauhan DS. Deep lobe parotid gland pleomorphic adenoma involving the parapharyngeal space. Med J Dr. DY Patil University. 2012;5(1):62.

6. Kansal L, Davessar JL, Singh G, Kaur J. Pleomorphic adenoma in para pharyngeal space: a rare presentation. Int J Otorhinolaryngol Head Neck Surg. 2017;3:455-8.

7. Basaran B, Polat B, Unsaler S, Ulusan M, Aslan I, Hafiz G. Parapharyngeal space tumours: the efficiency of a transcervical approach without mandibulotomy through review of 44 cases. Acta Otorhinolaryngologica Italica. 2014;34(5):310.

8. Horowitz G, Ari BO, Wasserzug O, Weizman N, Yehuda M, Fliss DM. The transcervical approach for parapharyngeal space pleomorphic adenomas: indications and technique. PLoS one. 2014;9(2):90210.

9. Hakeem AH, Hazarika B, Pradhan SA, Kannan R. Primary pleomorphic adenoma of minor salivary gland in the parapharyngeal space. World J Surg Oncol. 2009;7:85.

Cite this article as: Peruvaje V, Yogesh BN.

Pleomorphic adenoma of parapharyngeal space: a rare case report. Int J Otorhinolaryngol Head Neck Surg 2020;6:1198-200. 